\title{
Effective Factors on Alignment of Accounting Information Systems in Manufacturing Companies: Evidence from Iran
}

\author{
${ }^{*}$ Zohreh Hajiha ${ }^{1}$, Zo Alfaghar Pour Azizi ${ }^{2}$ \\ 1Department of Accounting, East Tehran branch, Islamic Azad University (IAU), Tehran, Iran \\ 2Department of Accounting, North Tehran branch Islamic Azad University (IAU), Tehran, Iran \\ *z_hajiha@yahoo.com
}

\begin{abstract}
This study examines accounting information systems (AIS) alignment and its effective factors in the context of manufacturing companies in industries of food and beverage, sugar, materials and pharmaceutical companies listed in Tehran Stock Exchange (TSE), in Iran. Strategic alignment is very important in increasing company's performance, however, few studies have been made to investigate the factors that affect alignment and therefore, in this study we aimed to identify different levels of AIS alignment of Iranian companies and then investigated the factors that affect in this alignment. We defined AIS alignment as adoption between AIS requirements and AIS capacity. Using a questionnaire, data from 81 companies (include their financial and executive managers) were gathered on nineteen accounting information specifications for both requirements and capacity of AIS. We applied moderation view for fitness between these two items. Then cluster analysis was applied to categorize companies in two groups of aligned and unaligned. The study then investigated some factors that might be related to AIS alignment. Findings indicate that AIS alignment was related to level of manager's accounting and IT knowledge; usage of accounting and audit firms as external experts of AIS; and usage of internal IT staff. The company size is also related to AIS alignment. It is important for companies to consider these effective factors on their AIS alignment so that opportunities can be recognized to improve AIS alignment that support their information needs in competitive environment.
\end{abstract}

Key words: Alignment, Accounting information system, fitness, management knowledge, experts.

\section{Introduction}

The main part of information needed for decision-making in organizations is accounting information. Since accounting is going to measure and present economic events to users in order to judge and decide knowingly, we know it as an information system. About accounting information system (AIS), American Accounting Association (AAA) says: Accounting information system is a part of Management Information System (MIS) that gathers, classifies, and compiles data in order to offer to internal and external decisionmakers. Therefore, regarding to importance, widely use and effectiveness of reports of AIS (Marriot and Marriot, 2000; Riemenschneider and Mykytyn Jr, 2000; and Ismail, 2007), managers need to exploit this information for success of their organizations (Ismail, 2009; Dastgir et al., 2003). For decision making, they need assurance that they are obtaining relevant, reliable and timely information with a reasonable cost (Kharuddin et al., 2010). IT has this advantage for AIS to help to provide such information. Nevertheless, it is difficult to gain competitive advantages without adoption or application of IT in companies. Computer technologies have increased the use of information systems such as AIS (Kharuddin et al., 2010). However, the AIS must be aligned to produce suitable information. The concept of alignment between information technology and business strategies are being discussed for many years, and this strategic alignment seems to be effective in improvement of performance of companies. Competitive market environment and informational needs of users are subjects that have a significant effect on alignment of information systems and organization performance. However, the factors affecting on alignment of AIS are not known yet and a few papers have been made to investigate the factors that influence alignment (Ismail and king, 2007). There are rare studies on AIS in Iran which imply Iranian companies are seeking rapid developments of IT. It needs new generation of knowledgeable managers who use information systems in strategic decision making (Marufkhani, 2000; Dastgir et al., 2003). Therefore, AIS became a strategic component in Iranian context. AIS alignment can provide a competitive competency to the companies. So, the research on AIS alignment could be interesting in Iranian context.

Many papers investigated the alignment between contingency factors and AIS design (Chong and Chong, 1997; Chenhall and Langfield-Smith 1998; Mia and Clarke, 1999) while some studies focused on 
alignment between contingency factors and IT sophistication (Weill and Olson, 1989; Henderson and Venkatraman, 1993; Bergeron et al., 2001). Chang and Jevons-Lee (1992) represented that the effects of these factors can be measured by the degree of a company information requirements which according to Bolon (1998) would be made available by companies investments in a more sophisticated information processing system. However, studies that focused on the alignment between information requirements and information processing capacity are very rare (Ismail and king, 2007). Studies of Dorociak (2007), Chan et al. (1997), and Cragg et al. (2002) show that many companies are looking for alignment. Nevertheless, there are few researches about the effective factors on this alignment especially in Iran.

So, the main objective of this study is to fill this gap by examining factors that have influence AIS alignment in the specific context of Iranian manufacturing companies. The study of influencing factors in Iran is important because Iranian companies have developed their own IT equipments as many other companies in developing countries do. Study of alignment of AIS in Iranian companies as a part of MIS helps to understand MIS and provides an insight to other developing countries. AIS alignment affects both financial and managerial aspects of accounting information. It can improve the information stream between the organization and both the inside and outside stakeholders.

Therefore, the aim of this study is to recognize some of these factors and their effects on alignment of AIS in the context of Iranian manufacturing companies listed in Tehran Stock Exchange (TSE) as an emerging economy. In order to do that, first we categorized the companies according to whether there was alignment or not between their accounting information system requirements (AIS requirements) and their accounting information system processing capacity (AIS capacity). Then, we tested the effects of some potential factors in two groups of aligned and non aligned companies to determine their relationships with AIS alignment.

\section{Literature Review}

This study applies the primary concepts of Information Processing Theory (IP theory). This theory identifies three important concepts: information processing requirements, information processing capacity, and the alignment between the two to obtain optimal performance. Organizations need qualified information to overcome environmental uncertainty and improve their decision making. Environmental uncertainty roots from the complexity of the environment and dynamism, or the frequency of changes to various environmental variables (Premkumar et al., 2005). IP theory implies that the fitness of information processing capacity has a significant effect on performance (Galbraith, 1973). The more complex the organization, the more its risk and ambiguity, and the more ambiguity the organization has, the more information must be processed to achieve the aimed performance (Bolon, 1998). Typically, organizations have two strategies to cope with uncertainty and increased information requirements: first, develop buffers to reduce the effect of uncertainty, and second, implement information processing capability to enhance the information flow and thereby reduce uncertainty (Premkumar et al., 2005). The organizations have to response to the increasing demand of accounting information by increasing their information processing capacity. To achieve this responsibility, organizations should generate the fit or alignment between this demand and the AIS capacity. So the recognition of these influencing factors on the alignment can affect organizational outcomes (Van de Van and Drazin, 1985).

According to the IP theory, the relationship between companies strategies alignment with information system is investigated in several studies (Tan, 1996; Li and Ye, 1999). These studies found a positive relationship between strategy and strategic information technology. IT investments will be more efficient if the systems implementation is aligned with the companies' strategy (Shin, 2001). This alignment between IT and business strategy has a positive effect on companies' performance (Cragg et al., 2002). Additionally, study of Dorociak (2007) deals with effects of alignment of organization strategies and information systems on performance. The scope of this study is small banks. The size of bank is measured by its number of personnel. The main hypothesis of this study is "there is a positive alignment between organization strategy, IT strategy, and organization performance", which was supported.

In addition, Davenport (1998) represented the importance of having a good fit between firms' requirement and technology capabilities. Some studies showed importance of IT in supporting informatic requirements for decision-making (eg. EL. Louadi, 1998; Temtime et al., 2003, Ismail and King, 2005). Researches showed that performance of companies with higher strategic alignment was better than others (Cragg et al, 2002; Bergeron et al., 2004). But there are few researches about effective factors on IT 
in companies (Bergeron, 2001; Hussin et al., 2002; Adekoya et al., 2005, Ismail and King, 2007). There are some studies about effective factors on IT success and alignment in organization that include IT complexity, management obligation, and business environment (Thong and Yap, 1995; Thong et al., 1996; Igbaria et al., 1997; Thong, 2001; Shiels et al., 2003; Raymond and St-Pierre, 2005; De Guinea et al., 2005). These studies showed that IT complexity, size of company, active role of manager, and using external expertise were important. However, there are few researches about accounting information systems and effective factors on this alignment. Study of Ismail and King (2007) in Malaysia about small and medium companies (SMEs) showed that IT sophistication, external experts, internal experts and owner/manager's knowledge affect alignment of accounting information system. Ismail (2009) also studied AIS effectiveness and its influence factors in SMEs in Malaysia. He found manager accounting knowledge and the effectiveness of vendors and accounting firms significantly were related to AIS effectiveness.

Support of top managers, participation of users in system development, users training and education, the concept of information systems group, and other organizational concepts like the size of company and task division were found as effective factors on performance. However, correlation of these factors with system performance is different and sometimes opposite. The results of this experimental study showed that factors like participation of users, number of personnel, and size of company affected performance of AIS. Also, it was indicated that the relation between system performance and effective factors is significantly affected by degree of information system evolution. Thus, different factors must be considered regarding to the degree of information system evolution (cited in Marufkhani, 2000). In Iran, Marufkhani (2000) studied effective factors on usage rate of managers from AIS to fulfill their duties. The statistical sample of this study was 56 companies listed in TSE. The results showed that 4 factors of familiarity of managers with information presentation, using suitable software, and completeness of information system affect usage of managers from AIS.

Dastgir et al. (2003) studied effect of AIS characteristics on improvement of decision-making of managers. This study considered 4 characteristics of to be understandable, relevance, reliable, and comparability as characteristics of AIS, and he studied the relation of each characteristic with improvement of decisionmaking by managers in 4 hypotheses. The statistical population of this study was managers of different levels of Bahman Corporation (an Iranian large automobile corporation), totally 50 persons. This study was done by questionnaires and 38 questionnaires were accepted. The results of this study showed that all the four characteristics affect decision-making of managers. As we searched there is no study on alignment of AIS requirements and AIS processing capacity in Iran, thus, this study aimed to provide further evidence about this issue in Iranian context. It could also add value to international context.

Hypotheses development of study: This study has 4 main and 2 subsidiary hypotheses. In this study, managers include chief executive managers and financial managers.

It is expected that those companies managers with more knowledge about IT and accounting system to be more successful in diagnosis of IT and accounting system requirements of their company (Marufkhani, 2000; Hussin et al., 2002; Ismail and King, 2007; Ismail, 2009) because they are in a situation to determine goals and strategies of the company (Thong, 1999). Therefore, the main first hypothesis of this study is:

$\mathbf{H}_{1}$ : companies that have managers with more knowledge about accounting and IT, have more alignment in AIS.

Regarding to the main first hypothesis, subsidiary hypotheses are as follow:

$\mathrm{H}_{1.1}$ : Managers with more knowledge about accounting, have more alignment in AIS.

$\mathrm{H}_{1.2}$ : Managers with more knowledge about IT, have more alignment in AIS.

Many studies emphasized on importance of consultants' role and experts in selection and implementation of computer systems of an organization (Igbaria et al., 1997; Thong, 1999; 2001; De Guinea, 2005). Experts were also emphasized in selection of AIS (Davis, 1997). Accountants and professionals play an important role in encouragement of a company for automation of its accounting process (Breen and Sciulli, 2002; Hartcher, 2003). Information of external experts helps diagnosing informational requirements and information process capacity. Therefore, it is expected that consulting with external experts can develop AIS alignment. Thus, the second hypothesis is:

$\mathbf{H}_{2}$ : Companies that use external experts, have more AIS alignment.

Accounting and financial staff of a company can help management in determination of managerial needs and AIS requirements. IT staff can also help management in determination of suitable technology to 
produce the required information (Ismail and King, 2007). Therefore, having employed internal experts can affect alignment of AIS. We used accounting and IT staff as internal experts of AIS. Thus the Hypothesis is:

\section{$\mathbf{H}_{3}$ : Companies with internal experts have more AIS alignment.}

The size of a company was always recognized as an effective factor on IT complexity (Ismail and King, 2007). Larger companies coincide better with IT and use it broader (Winston and Dologite, 1999). Thus, the fourth hypothesis is:

\section{$\mathbf{H}_{4}$ : Larger companies have more AIS alignment.}

The concept of alignment and fitness was discussed in the literature and there are many criteria to measure them. For example, Venkatraman (1989) presented 6 different aspects that alignment and fitness can be defined upon them. Among them moderation view for AIS was supported in some studies, including Ismail and King (2007); Cregg et al. (2002); Hussin et al. (2002); and Chan et al. (1997). Moderation view was also used in this study following Ismail and king (2007). This view assumes that alignment and fitness reflect the strategy. Fitness is as mutual action between AIS requirements and AIS capacity. The more the AIS capacity, the more the effects of AIS requirements on performance (Ismail and King, 2007).

\section{Methodology}

The research method was employed, is survey research. To measure requirements and capacity of AIS, we used the questionnaire of Chenhall and Morris (1986) and Ismail and King (2007). There are other tools that concentrated on financial accounting system, but they are more limited compared to the measurement tool in our study that included both financial accounting system and management accounting system (Ismail and King, 2007). This questionnaire was justified by the view of several experts in AIS for Iranian companies. This tool was also used in many studies of accounting (Mia, 1993; Abernethy \& Guthrei, 1994; Gul \& Chia, 1994; Chong \& Chong, 1997). For ethical issues, all questionnaires were distributed and gathered without name and identification of participants. The data gathered was used only in forms of statistical information and all participants were informed about it.

Research population and sample: Statistical population of this study are companies in industries of food and beverage, sugar, materials and pharmaceutical companies listed in Tehran Stock Exchange, which are 81 companies. Because of the limitation of the statistical population, sampling was not done and the whole population was selected as research sample. This population was selected because their information was more accessible from the database of TSE, and these industries were selected because they are in the basket of most families. It is expected that AIS alignment develops effectiveness and improves products and customer-orientation, and affect indirectly the wealth of society. A total of 162 participants eventually participated in the survey after a period of about two months and two follow-up reminders. However, 140 participants completed the survey and the response rate was about $86.4 \%$. Data gathering: As it was represented, data for characteristics of companies and their accounting systems was gathered through questionnaires by email or by researchers in person, during the months of November to December 2010. The respondents' email addresses and residential addresses were obtained through formal TSE website. The participants were chief executive managers and financial managers of sample companies. These managers were selected to be the respondents of this study because it is expected that they have valid perceptions of the AIS design and IT approach adopted by the companies. They usually make most key decisions about IT and AIS to achieve the company objectives and strategies (Jarvenpaa and Ives, 1991). Financial managers are also the persons who influence on the AIS decision making.

Validity and reliability of study: The questionnaire of Ismail and King (2007) for Malaysian companies was utilized for this study, after required adjustment; so there is validity. Chronbach's Alpha test was used for reliability. Chronbach Alpha factor 0.82 was obtained for 30 questionnaires, so the study is reliable (more than 0.7).

Definition and measurement of variables: This study has 4 independent variables and one dependent variable. AIS alignment is the dependent variable, and management knowledge, usage of external experts, 
usage of internal experts, and size of company are the independent variables. The following sections explain how each of the variables in the research was measured.

AIS Alignment: as it was explained in earlier sections, AIS alignment is defined as interaction of two factors of AIS requirements and capacity (Ismail and King, 2007). AIS requirements is the importance level of 19 specifications, suggested in the questionnaire. AIS capacity is the access of companies to these 19 specifications. Both variables were measured by these 19 specifications. They are: Frequency of reporting, Summary reports of organization, Summary reports of sections, Sectional reports, Speed of reporting, Temporal reports, Future events, Immediate reporting, Non-financial information on production, Automatic receipt, Decision making models, Organizational effect, Precise targets, Nonfinancial information on market, Effects of events on functions, Sub-unit interaction, Non-economic information, What-if analysis, External information(Ibid).

Management knowledge: Management knowledge was measured by familiarity of managers with 9 main operations of companies. Thus, lists including these 9 operations were given to the respondents to indicate their familiarity with these concepts. These 9 concepts are: Management accounting techniques, Financial accounting techniques, Usage of data processing software, Spread sheet, Database, Accounting applications, Email, Internet, and Computer based production management. The average of the scores obtained by respondents was considered as management knowledge.

External and External experts: Regarding to the literature, external experts include consultants, suppliers, governmental organizations, and accounting and audit firms. If a company uses one of these experts, 1 score is given. Internal experts include full-time staff of accounting and IT departments. If a company uses one of these experts, 1 score is given.

Size of company: There are many criteria to measure size of a company including assets, sale rate, number of staff, etc. Number of staff is the most common criterion. This criterion was used in European Union Act and Iran Labor Act to distinguish small, medium, and large companies. So, it is used here.

For AIS alignment measuring, AIS requirement and AIS capacity variables were measured in relation to nineteen accounting information specifications using two separate five-point scales in the questionnaire. First, the managers were asked to indicate their perception of importance of each of 19 specifications (1=not important, $5=$ =ery important). Then, they were asked to score the extent of accessibility of each specification in their computer based information system ( $1=$ no access, $5=$ full access).

We applied moderation view that is one of the most common approaches and was used by many researchers. In this view, for each company and each information specification, the AIS alignment was measured by multiplying the rating of an AIS requirement item with the rating of the corresponding AIS capacity item (Ismail and King, 2007). In this method, a high rate for both of AIS requirement item and the corresponding AIS capacity item will result in a high alignment score and vice versa. Therefore, since each item was measured using a five-point scale, the multiplication of these scores is between 1 and 25(Chan et al., 1997; Ismail and king, 2007).

Then we used cluster analysis to recognize similar groups based on the nineteen measures of AIS alignment. So we had two categories of aligned and not aligned companies in the sample. Total statistical sample includes 81 companies. We sent 162 questionnaires to their managers and 140 questionnaires were received (from 70 companies). Out of 140 completed questionnaires, 55 were from aligned group and 85 questionnaires were from unaligned group of AIS. Further we applied Levene's Test for Equality of Variances and T- Independent Samples Test to data analyze and hypotheses test in 95\% confidence level.

\section{Results}

Descriptive Statistics: Table 1 shows frequency distribution of age of respondents in two positions of executive managers and financial managers. 
Table 1: Descriptive statistics of participants

\begin{tabular}{llll}
\hline $\begin{array}{c}\text { Descriptive } \\
\text { Statistics }\end{array}$ & \multicolumn{1}{c}{$\begin{array}{c}\text { Years of experience in } \\
\text { management }\end{array}$} & $\begin{array}{c}\text { Years of experience in } \\
\text { accounting }\end{array}$ & Age \\
\hline $\mathrm{N}$ & 140 & 140 & 140 \\
Mean & 11.6929 & 10.4714 & 42.6643 \\
Median & 12 & 10 & 43 \\
Mod & 15 & 15 & 45 \\
Std Deviation & 3.11159 & 4.845 & 4.44731 \\
Variance & 9.682 & 23.474 & 19.779 \\
Minimum & 4 & 0 & 30 \\
Maximum & 19 & 22 & 52 \\
\hline
\end{tabular}

As the table indicates, the least ages were 30 and 31 for executive managers and financial managers, respectively. The most ages were 50 and 52 . The most age was 45 . Also, from the respondents, 4 had doctorate degrees, 18 had master degrees, 103 had bachelor degrees, and 15 had associate degrees. Table 2 shows descriptive statistics for the gender of respondents.

Table 2: Descriptive statistics for gender

\begin{tabular}{cccc}
\hline \multirow{2}{*}{ Gender } & \multicolumn{2}{c}{ Position } & \multirow{2}{*}{ Sum } \\
\cline { 2 - 3 } & Financial managers & Executive managers & \\
\cline { 1 - 2 } Male & 57 & 51 & 108 \\
Female & 13 & 19 & 32 \\
Sum & 70 & 70 & 140 \\
\hline
\end{tabular}

Hypotheses testing: The main goal of this paper is to examine some factors that affect AIS alignment. To do this, first the alignment between AIS requirements and AIS capacity were determined using the moderation view and questionnaire tool. Then, using cluster analysis, companies were grouped according to their degree of AIS alignment. Finally, we tested the differences of 4 effective factors (Management knowledge, External experts, internal experts and Size) in two groups of aligned ant not aligned companies about AIS. Each hypothesis was tested by T-test.

Test of the first hypothesis: We examined the association between AIS alignment and management knowledge in the first hypothesis. Management knowledge was measured by familiarity of managers with 9 main operations. These 9 operations divide into two maim categories: IT knowledge and Accounting Knowledge (according to Ismail and King's study). Thus, lists including 9 operations that were given to the respondents to indicate their familiarity with each concept ( 1 =not-familiar, $5=$ full familiar). These 9 operations are: Financial accounting techniques, Management accounting techniques ( the category of Accounting Knowledge) and Word processing software, Spreadsheets, Databases, Accounting applications, Computer-based production management, Email and Search in the internet (the category of IT Knowledge). The results for T-test are shown in tables 3 and 4 .

Table 3: Descriptive statistics for the first hypothesis

\begin{tabular}{lccccc}
\hline Variable & The kind of company & $\begin{array}{c}\text { Std. Error } \\
\text { Mean }\end{array}$ & $\begin{array}{c}\text { Std. } \\
\text { Deviation }\end{array}$ & Mean & Number \\
\hline Management & Aligned & 0.03726 & 0.2763 & 4.0848 & 55 \\
knowledge & Not aligned & 0.02898 & 0.26716 & 3.4118 & 85 \\
\hline
\end{tabular}




\begin{tabular}{|c|c|c|c|c|c|c|c|c|}
\hline \multirow[b]{2}{*}{ Hypothesis } & \multirow[b]{2}{*}{ Variable } & \multirow[b]{2}{*}{ Statistics } & \multicolumn{3}{|c|}{ t-test for Equality of Means } & \multirow[b]{2}{*}{$\mathbf{t}$} & \multicolumn{2}{|c|}{$\begin{array}{c}\text { Levene's Test for } \\
\text { Equality of } \\
\text { Variances } \\
\end{array}$} \\
\hline & & & $\begin{array}{c}\text { Mean } \\
\text { Difference }\end{array}$ & $\begin{array}{l}\text { Sig. (2- } \\
\text { tailed) }\end{array}$ & df & & Sig. & $\mathbf{F}$ \\
\hline $\begin{array}{l}\text { Main first } \\
\text { hypothesis }\end{array}$ & $\begin{array}{l}\text { management } \\
\text { knowledge }\end{array}$ & $\begin{array}{l}\text { Equal } \\
\text { variances } \\
\text { assumed } \\
\text { Equal } \\
\text { variances not } \\
\text { assumed }\end{array}$ & 0.67308 & 0 & 112.606 & 14.364 & 0.395 & 0.728 \\
\hline $\begin{array}{l}\text { First sub- } \\
\text { hypothesis }\end{array}$ & $\begin{array}{l}\text { Accounting } \\
\text { Knowledge }\end{array}$ & $\begin{array}{l}\text { Equal } \\
\text { variances } \\
\text { assumed } \\
\text { Equal } \\
\text { variances not } \\
\text { assumed }\end{array}$ & 0.30535 & 0 & 84.903 & 3.803 & 0.008 & 7.334 \\
\hline $\begin{array}{l}\text { Second sub- } \\
\text { hypothesis }\end{array}$ & $\begin{array}{l}\text { IT } \\
\text { Knowledge }\end{array}$ & $\begin{array}{l}\text { Equal } \\
\text { variances } \\
\text { assumed } \\
\text { Equal } \\
\text { variances not } \\
\text { assumed }\end{array}$ & 0.60523 & 0 & 123.197 & 14.637 & 0.947 & 0.004 \\
\hline
\end{tabular}

The significance level in the first row of table 4 is 0.39 (more than \%5), so equal variances are assumed. Therefore, $t$ statistic under variances equality was 14.36 and significance level was $0.0 \tilde{0}$, as a result the hypothesis is supported by $95 \%$ of confidence. In other words, the average of management knowledge in aligned companies is not significantly equal with that of unaligned companies. Regarding to table 3 , the average of management knowledge for aligned group is significantly more than that of unaligned group (4.08 against 3.411).

The first hypothesis divided into two sub-hypotheses. We examined them separately. According to the table 4 about the first sub- hypothesis (the relation between accounting knowledge of managers and AIS alignment), the significance level was sig $=0.008$, which is less than 0.05 . So, variances of two groups were not assumed equal. Since t statistic was 3.80 and sig $=0.000$ (less than $5 \%$ ) under variances equality, then the first sub-hypothesis is supported. In other words, the average of management accounting knowledge is not equal in aligned and unaligned companies. The average of management accounting knowledge in aligned group is significantly more than that of unaligned group. Therefore, the first sub-hypothesis is confirmed.

For the second sub-hypothesis (the relation between IT knowledge of managers and AIS alignment), regarding to Levene's Test for Equality of Variances in table 4, the significance level was sig $=0.947$, which is more than 0.05 . So, variances of two groups are equal. Since $t$ statistic is 14.63 and sig $=0.000$ under variance inequality, then the second sub-hypothesis is confirmed. In other words, the average of management IT knowledge in aligned companies is significantly more than that of unaligned companies.

Test of the second hypothesis: In this study, consultants, raw material suppliers, governmental organizations, and accounting and audit firms were considered as external experts. Managers were asked if they had used these experts in their company. Table 5 shows the amount of usage of external experts. As table 5 shows, none of the companies utilized external experts from any government organizations. Besides governmental organizations and consultants which are the same in two groups, the usage of other external experts is mixture of two groups of companies. 
Table 5: Usage of external experts

\begin{tabular}{lccrrrrrrr}
\multicolumn{1}{c}{$\begin{array}{c}\text { External } \\
\text { factors }\end{array}$} & \multicolumn{2}{c}{ Consultants } & \multicolumn{2}{c}{$\begin{array}{c}\text { Raw material } \\
\text { suppliers }\end{array}$} & \multicolumn{2}{c}{$\begin{array}{c}\text { Governmental } \\
\text { organizations }\end{array}$} & \multicolumn{2}{c}{$\begin{array}{c}\text { Accounting and } \\
\text { audit firms }\end{array}$} \\
companies & Number & Percent & Number & Percent & Number & Percent & Number & Percent \\
\hline $\begin{array}{l}\text { Aligned } \\
\text { group }\end{array}$ & 28 & 100 & 10 & 36 & 0 & 0 & 24 & 86 \\
$\begin{array}{l}\text { Not aligned } \\
\text { group }\end{array}$ & 42 & 100 & 29 & 69 & 0 & 0 & 13 & 31 \\
Total & 70 & 100 & 39 & 56 & 0 & 0 & 37 & 53 \\
\hline
\end{tabular}

Table 6 shows the test hypothesis results. In the table, regarding to Levene's Test, the significance level is sig $=0.11$, which is more than 0.05 . So, variances of two groups are equal. Since t statistic is 1.59 and sig $=0.16$ (more than $5 \%$ ) under variances inequality, then the second hypothesis is not supported. In other words, the average of usage of external experts in aligned companies is equal to that of unaligned companies. Therefore, the second hypothesis is rejected.

Table 6: T-test for the second hypothesis

\begin{tabular}{lllllllll}
\hline \multirow{2}{*}{ Variable } & Statistics & \multicolumn{3}{c}{ t-test for Equality of Means } & \multicolumn{3}{c}{$\begin{array}{c}\text { Levene's Test for } \\
\text { Equality of Variances }\end{array}$} \\
\cline { 2 - 8 } & $\begin{array}{l}\text { Mean } \\
\text { Difference }\end{array}$ & $\begin{array}{l}\text { Sig. (2- } \\
\text { tailed) }\end{array}$ & df & t & Sig. & F \\
\hline \multirow{2}{*}{$\begin{array}{l}\text { External } \\
\text { experts }\end{array}$} & $\begin{array}{l}\text { Equal variances } \\
\text { assumed }\end{array}$ & 0.05357 & 0.116 & 68 & 1.591 & 0.11 & 2.616 \\
& $\begin{array}{l}\text { Equal variances } \\
\text { not assumed }\end{array}$ & 0.05357 & 0.121 & 56.029 & 1.576 & & \\
\hline
\end{tabular}

Test of the third hypothesis: In this study, accounting staff and IT staff were considered as internal experts. Company's managers were asked if they used these experts. Table 7 shows usage of internal experts. The results in table 7 show that the percentage of accounting staff is much higher than the percentage of IT staff in both aligned and non aligned companies. What is interesting is that all companies used from accounting staff while aligned companies used IT staff more.

Table 7: Usage of internal experts

\begin{tabular}{lllll}
\hline Internal factors & \multicolumn{2}{l}{ Accounting staff } & \multicolumn{2}{c}{ IT staff } \\
\hline companies & Number & Percent & Number & Percent \\
\hline Aligned group & 28 & 100 & 22 & 79 \\
Not aligned group & 42 & 100 & 13 & 31 \\
Total & 70 & 100 & 35 & 50 \\
\hline
\end{tabular}

The results of examination for third hypothesis are shown in table 8. Regarding to Levene's Test, the significance level was 0.73 , which is more than 0.05 . So, variances of two groups are assumed equal. Since $\mathrm{t}$ statistic is 4.35 and sig $=0.00$ under variances inequality, then the average of internal experts in aligned companies is not equal to that of unaligned companies, and the average for aligned group is more than that of unaligned group. Therefore, the third hypothesis is supported. However, it seems this difference is related to the usage of IT staff in aligned companies.

Table 8: T-test for the third hypothesis

\begin{tabular}{llccccccc}
\hline Variable & \multicolumn{1}{c}{ statistics } & \multicolumn{3}{c}{ t-test for Equality of Means } & \multicolumn{4}{c}{$\begin{array}{c}\text { Levene's Test for } \\
\text { Equality of Variances }\end{array}$} \\
& $\begin{array}{c}\text { Mean } \\
\text { Difference }\end{array}$ & $\begin{array}{l}\text { Sig. (2- } \\
\text { tailed) }\end{array}$ & df & t & Sig. & F \\
$\begin{array}{l}\text { Internal } \\
\text { experts }\end{array}$ & $\begin{array}{l}\text { Equal variances } \\
\text { assumed }\end{array}$ & 0.2381 & 0 & 68 & 4.35 & 0.073 & 3.307 \\
& $\begin{array}{l}\text { Equal variances } \\
\text { not assumed }\end{array}$ & 0.2381 & 0 & 62.326 & 4.45 & & \\
\hline
\end{tabular}


Test of the fourth hypothesis: The number of employees was used to measure size of a company. Table 9 shows the average of employees of companies in two groups.

Table 9: Size of company

\begin{tabular}{lrr}
\hline Kind of company & Average of total employees & Average of accounting staff \\
\hline Aligned companies & 991 & 16 \\
Not aligned companies & 569 & 63 \\
Total & 738 & 84 \\
\hline
\end{tabular}

Table 10 represents the test results. Regarding to Leven's Test, the significance level was sig=0.047, which is less than 0.05 . So, variances of two groups are unequal. Since T statistic is 6.007 and sig $=0.000$ under variance inequality, then the average of size of company in aligned companies is not equal to that of unaligned companies, and the average for aligned group is more than that of unaligned group. Therefore, the fourth hypothesis is supported.

Table 10: T-test for the fourth hypothesis

\begin{tabular}{llllllll}
\hline \multirow{2}{*}{ Variable } & Statistics & \multicolumn{3}{c}{ t-test for Equality of Means } & \multicolumn{3}{c}{$\begin{array}{c}\text { Levene's Test for } \\
\text { Equality of Variances }\end{array}$} \\
\cline { 2 - 8 } & $\begin{array}{l}\text { Mean } \\
\text { Difference }\end{array}$ & $\begin{array}{l}\text { Sig. (2- } \\
\text { tailed) }\end{array}$ & df & t & Sig. & F \\
\hline $\begin{array}{l}\text { Company } \\
\text { size }\end{array}$ & $\begin{array}{l}\text { Equal variances } \\
\text { assumed }\end{array}$ & 236.881 & 0 & 68 & 6.454 & 0.047 & 4.091 \\
& $\begin{array}{l}\text { Equal variances } \\
\text { not assumed }\end{array}$ & 236.881 & 0 & 44.029 & 6.007 & & \\
\hline
\end{tabular}

Discussion: The factors affecting AIS alignment and fitness were studied in this paper. Fitness of accounting information system is interrelation between AIS requirements and AIS capacity (Premkumar et al., 2005). We used the moderation view to measure fitness by degrees of alignment through the 19 accounting information specifications. In the research, the questionnaire of Chenhall and Morris (1986) and Ismail and King (2007) was used with some adjustment for business environment of Iran.

The companies in food and beverage, sugar, materials and pharmaceutical industries listed in TSE, 81 companies, were investigated. This study has 4 independent variables and one dependent variable. AIS alignment is the dependent variable, and management knowledge, usage of external experts, usage of internal experts, and size of company are the independent variables. The companies were divided into two aligned and unaligned groups by cluster analysis method and the two groups of companies were compared for each independent variable. Results of this study suggest that some Iranian manufacturing companies had achieved to alignment between AIS requirements and AIS capacity, while the others had not.

According to the test results of first hypothesis, management knowledge (in two categories of accounting and IT knowledge of managers) had association with AIS alignment in Iranian context. The results showed that the average of management knowledge in aligned group is significantly more than that of unaligned group. This finding is consistent with that of Ismail and King (2007) for Malaysian small and medium companies, however; in our study the results support the hypothesis 1 stronger. In examination of hypothesis 2, the average of usage of external experts in aligned companies was equal to that of unaligned companies. So, the second hypothesis was not supported. In this study, consultants, suppliers, governmental organizations, and accounting and audit firms were considered as external experts. Nearly, all companies have used consultants. Thus, usage of consultants had no effect on alignment of AIS. This finding is opposite of that of Ismail and King (2007).

The results of test of the third hypothesis indicated that internal experts in aligned group were significantly more than that of unaligned group. In this study, accounting and IT personnel was considered as internal experts. All companies in two groups used accounting personnel. So, the average of this variable was equal in both groups and had no effect on alignment. However, usage of information system personnel in aligned companies was more than that of unaligned companies. Therefore, it is 
concluded that usage of information system personnel affects alignment of AIS. This result is consistent with the findings of Ismail and King (2007).

Finally, the average of size of company in aligned group was larger than that of unaligned group. The size has long been recognized as one of the factors that affects IT usage in the company. Generally, larger companies adopt or make use of IT (Winston and Dologite, 1999). Smaller companies have more limited resources and lack of formalization of information systems structure (Thong, 2001). Therefore, it is expected that larger companies achieve higher degrees of AIS alignment, what is supported in this study. However, this is opposite of the result of Ismail and King Study, one possible reason is that they investigated small and medium companies, and as a result their study limited the size variable.

\section{Conclusion and Recommendations}

The findings on first hypothesis testing indicate in Iranian companies, managers step regarding to their knowledge toward improvement of AIS alignment. In Iran, Marufkhani (2000) studied effective factors on usage of managers from AIS. The results showed some mangers knowledge, and completeness of information system affected usage of managers from AIS in Iran. The comparison of the results of present paper with Marufkhani's study indicates there is a mutual relation between knowledge of managers and improvement and usage of AIS. Findings from the test of hypothesis 2 indicate in Iranian companies, few unaligned companies have not used suppliers even the usage is more than aligned companies. So, usage of suppliers had no effect on alignment. It implies that Iranian companies can not use from these experts to alignment improvement of AIS. In addition, no member used governmental organization. This finding is not consistent with Ismail and King (2007) for Malaysian SMEs.

It can relate to the position of governmental organizations and the poor reaction between public and private sectors in Iran. But usage of accounting and audit firms in aligned group was more than that of unaligned group, so it can be concluded that companies had utilized from these firms to improve their AIS alignment. In other words, usage of accounting and audit firms in aligned companies was more than that of unaligned companies. Since these firms are more knowledgeable about their clients and their clients' businesses and they can help them to achieve better AIS alignment. This finding is consistent with Ismail and King Study for Malaysian SMEs. In a wider context about information systems and IT alignment some studies indicated the effect of external experts on alignment (Thong and Yap, 1995; Thong et al., 1996; Igbaria et al., 1997; Thong, 2001; Shiels et al., 2003; Raymond and St-Pierre, 2005; De Guinea et al., 2005), however, in total the result of this paper does not support hypothesis 2. Internal experts (accounting IT and staff) have different effects on AIS alignment. Both aligned and non aligned companies had accounting staff, however, they had no significant impact on AIS alignment. In contrast, IT staff had significant different in two groups of companies. In other words, aligned companies used IT staff more than non aligned companies. The possible reason is the force of external reporting requirement that needs accounting staff. These staff however can not help to improve AIS alignment, while the existence of IT staff is usually voluntary and the managers use these experts based on their needs and so profit from their advice to alignment improvement of AIS. Finally, company size has significant impact on AIS alignment. It is expected that larger companies have more facilitations to improve IT equipments, they can utilize to IT consultants and benefit from more well known and expensive AIS software in Iran.

Totally, it can be concluded that in Iranian companies in sample industries with aligned AIS, management knowledge and internal experts are more than those of unaligned companies, and usage of external experts could not help AIS alignment. Also, larger companies have more AIS alignment.

Limitations: Although the discussion of information systems is very important, however, limitations cause researchers pay less attention to this. In this research, the usage of questionnaire in nature has limitations. There are also so many limitations in the study that can be addressed in future research. One limitation is related to the sample bias that might affect the generalization of the findings to the large population because we selected only some industries in TSE. Other Iranian companies in sample industries which are not listed in TSE were ignored in our study that can limit the results. However, their data are not available to investigate. Additionally, to generalize the findings to international context, researchers should be able to have access to companies in emerging and developing countries like Iran which has so many problems to provide appropriate IT for AIS alignment. These problems do not exist in developed countries. It seems external stakeholders in Iranian companies are not consider as value chain elements. So to improve the value chain, companies should enhance their relations with external experts 
like governmental agencies and suppliers. Both these experts can be an important component in value chain of the companies. The improvement of these relations not only creates more value among the all the value chain, but also influences information management and information systems alignment. Therefore, the following items are mentioned for future studies:

- Because of some limitations, the statistical population and sample of this study was only several industries in TSE. It is recommended to investigate other industries. It can be helpful to investigate Iranian small and medium companies in particular and to compare the results with this study and Ismail and king study too.

- There is alignment discussions in all levels of an organization and it can be tested in each MIS sub-system and not only AIS. Researchers can study the effects of these factors on other information systems of an organization.

- In the future, research can be concentrated on other methods for AIS alignments and other potential variables on AIS alignment.

\section{References}

Abernethy, M. A. \& Guthrie, C. H. (1994). An empirical assessment of the "fit" between strategy and management information system design. Accounting and Finance, 34(2), 49-66.

Adekoya, A. A., Eyob, E. Ikem, F. M., Omojokun, E. O. Quaye, A. M. \& Bada, A. O. (2005). Dynamics of information technology (IT) successful implementation in development countries: A Nigerian case study. The Journal of Computer Information Systems, 45(3), 107-112.

Bergeron, F. Raymond, L. \& Rivard, S. (2001). Fit in strategic information technology management research: An empirical comparison of perspectives. OMEGA The International Journal of Management Science, 29(2), 125-142.

Bergeron, F., Raymond, L. \& Rivard S. (2004). Ideal patterns of strategic alignment and business performance. Information \& Management, 41(8), 1003-20.

Bolon, D. S. (1998). Information processing theory: Implications for health care organizations. International Journal of Technology Management, 15(3,4,5), 211-221.

Breen, J. \& Sciulli N. (2002). Use of Computerized Record Keeping in Small Business, Small business Research Unit, Victoria University.

Chan, Y. E., Huff, S. L., Barclay, D. W. \& Copeland, D. G. (1997). Business strategic orientation, information systems strategic orientation, and strategic alignment. Information Systems Research, 8(2), 125150.

Chang, C. H. \& Jevons-Lee, C. W. (1992). Information acquisition as business strategy. Southern Economic Journal, 58(3), 750-761.

Chenhall, R. H. \& Langfield, S. K. (1998). Adoption and benefits of management accounting practices: an Australian study. Management Accounting Research, 9(1), 1-19.

Chong, V. K. \& Chong, K. M. (1997). Strategic choices, environmental uncertainty and SBU performance: a note on the intervening role of management accounting systems. Accounting and Business Research, 27(4), 268-276.

Cragg, P. B. King, M. \& Hussin, H. (2002). IT alignment and firm performance in small manufacturing firms. Journal of Strategic Information Systems, 11(2), 109-132.

Dastgir, M. Jamshidian, M. \& Jadidi, A. (2003). The affect of characteristics of AIS on managers' decision making improvement. Iranian Accounting Review, 34(2), 54-79.

Davenport, T. H. (1998). Putting the Enterprise into the Enterprise System, Harvard Business Review, 76(4), 121-131.

Davis, M. (1997). Transforming your firm: Tools for successful technology consulting. The Practical Accountant, 30(8), S-3.

De Guinea, A. O., Kelley, H. \& Hunter, M. G. (2005). Information systems effectiveness in small businesses: Extending a Singaporean model in Canada. Journal of Global Information Management, 13(3), 5579.

Dorociak, J. (2007). The alignment between business and information system strategies. Capella university. School of business and technology.

El Louadi, M. (1998). The relationship among organization structure, information technology and information processing in small Canadian firms. Canadian Journal of Administrative Sciences, 15(2), 180-199.

Galbraith, J. R. (1973). Designing Complex Organizations, Addison-Wesley, Reading, Mass. Green, P.E., Tull. 
Gul, F. A. \& Chia, Y. M. (1994). The effects of management accounting systems, perceived environmental uncertainty and decentralization on managerial performance: a test of three-way interaction. Accounting, Organizations and Society, 19(4/5), 413-426.

Hartcher, J. (2003). Small Business Survey Program: Financial Management, Insolvency and Fraud, CPA Australia. Available at: http://www.aic.gov.au/crime_types/economic/business/fraud.aspx.

Henderson, J. C. \& Venkatraman, N. (1993). Strategic alignment: Leveraging information technology for transforming organizations. IBM Systems Journal, 32(1), 4-16.

Hussin, H. King, M. \& Cragg, P. B. (2002). IT alignment in small firms. European Journal of Information Systems. 11(1), 108-127.

Igbaria, M., Zinatelli, N., Cragg, P. B. \& Cavaye, A. L. M. (1997). Personal computing acceptance factors in small firms: A structural equation model. MIS Quarterly, 21(3), 279-305.

Ismail, N. A. (2009). Factors influencing AIS effectiveness among manufacturing SMES: Evidence from Malaysia. The Electronic Journal on Information Systems in Developing Countries. 38(10), 1-19

Ismail, N. A. (2007). The impact of information technology on performance: The mediating role of management accounting systems. Jurnal Teknologi 46(E), 27-44.

Ismail, N. A. \& King, M. (2007). Factors Influencing the Alignment of Accounting Information Systems in Small and Medium Sized Malaysian Manufacturing Firms. Journal of Information Systems and Small Business, 1(1/2), 1-19.

Ismail, N. A. \& King, M. (2005). Firm performance and AIS alignment in Malaysian SMEs. International Journal of Accounting Information Systems, 6(4), 241-259.

Jarvenpaa, S. L. \& Ives, B. (1991). Executive involvement and participation in the management of information technology. MIS Quarterly, 15(2), 205-227.

Kharuddin, S. Ashhari, A. \& Nassir, A. M. (2010). Information System and Firms' Performance: The Case of Malaysian Small Medium Enterprises. International Business Research, 3(4), 28-35.

Li, M. \& Ye, L. (1999). Information technology and firm performance: Linking with environmental, strategic and managerial context, Information Management, 35(1), 43-52.

Marufkhani, M. (2000). Affecting factors on the use of managers from AIS to improve manager's goals. Thhe university of Tehran.Uunpublished master dissertation, Iran.

Marriot, N. \& Marriot, P. (2000). Professional accountants and the development of a management accounting service for the small firm: Barriers and possibilities. Management Accounting Research, 11(4), 475-492.

Mia, L. (1993). The role of MAS information in organisations: an empirical study. British Accounting Review, 25(3), 269-285.

Mia, L. \& Clarke, B. (1999). Market competition, management accounting systems and business unit Performance. Management Accounting Research, 10(2), 137-158.

Premkumar, G. Ramamurthy, K. \& Saunders, C. S. (2005). Information processing view of organizations: An exploratory examination of fit in the context of interorganizational relationships. Journal of Management Information Systems, 22(1), 257-294.

Raymond, L. \& St-Pierre, J. (2005). Antecedents and performance outcomes of advanced manufacturing systems sophistication in SMEs. International Journal of Operations \& Production Management, 25(5/6), 514-533.

Riemenschneider, C. K. \& Mykytyn Jr, P. P. (2000). What small business executives have learned about managing information technology. Information and Management, 37(3), 257-269.

Shiels, H., McIvor, R. \& O'Reilly, D. (2003). Understanding the implications of ICT adoption: Insights from SMEs. Logistics Information Management, 16(5), 312-326.

Shin, N. (2001). The impact of Information Technology on Financial Performance: The importance of Strategic Choice. European Journal of Information Systems, 10(4), 227-236.

Tan, R. R. (1996). Information technology and perceived competitive advantage: an empirical study of engineering consulting firms in Taiwan. Construction Management Economics, 14(3), 227-240.

Temtime, Z. T., Chinyoka, S. V. \& Shunda, J. P. W. (2003). Toward strategic use of IT in SMEs: a developing country perspective. Information Management and Computer Security, 11(5), 230-237.

Thong, J. Y. L. \& Yap, C. S. (1995). CEO characteristics, organizational characteristics and information technology adoption in small businesses. OMEGA International Journal of Management Science, 23(4), 429-442.

Thong, J. Y. L., Yap, C. S. \& Raman, K. S. (1996). Top management support, external expertise and information systems implementation in small businesses. Information Systems Research, 7(2), 248-267.

Thong, J. Y. L. (1999). An integrated model of information systems adoption in small business. Journal of Management Information Systems, 15(4), 187-214. 
Thong, J. Y. L. (2001). Resource constraints and information systems implementation in Singaporean small business. OMEGA International Journal of Management Science, 29(2), 143-156.

Van de Ven, A. H. \& Drazin, R. (1985). The concept of fit in contingency theory. Research in Organizational Behavior, 7(3), 333-365.

Venkatraman, N. (1989). The concept of fit in strategy research: toward verbal and statistical correspondence. Academy of Management Review, 14(3), 423-444.

Weill, P. \& Olson, M.H. (1989). An assessment of the contingency theory of management information systems. Journal of Management Information Systems, 6(1), 59-85.

Winston, E. R. \& Dologite, D. G. (1999). Achieving IT infusion: A conceptual model for small business. Information Resources Management Journal, 12(1), 26-38. 